\title{
Moral Judgment behind Prosocial Value Endorsing Online Crowdlending Behavior: Consequentialism vs. Deontology
}

\author{
Sheila Putri Fajrianti ${ }^{1}$ and Juneman Abraham ${ }^{2}$ \\ \{spfajrianti@gmail.com, juneman@binus.ac.id \} \\ 1,2Department of Psychology, Bina Nusantara University, Jl. Kemanggisan Ilir III no. 45, DKI Jakarta, \\ Indonesia
}

\begin{abstract}
This study aimed at investigating the role of consequentialist and deontological moral judgment in predicting online prosocial value endorsing crowdlending behavior. Using multiple linear regression on 198 participants (93 males, 105 females; mean of age $=30.56$ years old, standard deviation of age $=6.06$ years $)$, it is found that consequentialism $(\beta=0.456, p<0.01)$ and deontology $(\beta=0.149, p<0.01)$ can predict prosocial value.
\end{abstract}

Keywords. Online Prosocial Behavior, Crowdlending, Moral Judgment, Value, Consequentialism, Deontology

\section{Introduction}

The number of entrepreneurship in Indonesia is relatively small, 3.1 percent from the total population (Kementerian Koperasi dan Usaha Kecil dan Menengah, 2017). Various problems are faced by small enterprise practitioners, ranging from idea development, mathematical calculation and technique, execution, to the most crucial one, capital (Uddin, 2014). Many innovative new business ideas and concept developments are hindered by the lack or absence of initial capital (Ghanimeh, 2015). The report of Bank Indonesia in 2015 stated that $60 \%$ to $70 \%$ small enterprise practitioners had no access to funding from banks (Bank Indonesia, 2015). Bernhard Soebiakto (cited in Sulaiman, 2015) said that the difficulty in small enterprise capital can be solved not only through government's or financial institution's programs but also through society's involvement This opinion is supported by Galak, Small and Stephen (2011), who emphasized the importance of developing a microfinance system that can facilitate society to support needy small enterprises. The concept is known as crowdlending.

Crowdlending is derived from crowdfunding activity, which is an open request for financial aid via the internet with products, services, or goods in return (Gerber, Hui and Kuo, 2012; Gerber, et al, 2014). Crowdfunding is a process where everyone can donate money to realize an idea, concept or issue that are regarded important, interesting, and significant (Hemer, 2011; Gerber, et al, 2014).

When individuals participate in lending funds through crowdlending, they demonstrate prosocial behavior, a behavior aimed or intended to give benefits to or advantages over other parties. (Penner, Dovidio, Piliavin and Schroeder, 2005; Underwood and Moore, 1982). 
Altruism (i.e. the willingness to help others that is free from self-interest and often requires cost from the actor) and norm of reciprocity values are two main motives behind a prosocial behavior (Aronson et al, 2016; Lampridis and Papastylianou, 2014; Wang and Wang, 2008).

People seem to agree that contributing in crowdlending as fund lenders is a good thing. But why? In order to exhibit a prosocial behavior, individuals must regard or perceived that the behavior is a good behavior and is appropriate to be done. moral judgment is a complex blend of cognitive and affective components that help individuals judge whether a behavior or event is good or bad (Eisenberg, 1982). This present study aimed at finding out what moral judgments are involved in online prosocial value, consequentialism and/or deontology.

Consequentialism embraces the principle that a behavior can be morally justified if the behavior brings positive impacts for most society (Spielthenner, 2005; Tiberius and Plakias, 2010). Even though it requires hard work or is even against the prevailing norms at some points, a behavior must be exhibited on behalf of people's happiness and welfare (Larry and Moore, 2016). In crowdlending participation, someone can adopt the logic of this perspective that his/her helping behavior is exhibited to reach a satisfying result and the welfare of others. Adopting consequentialism, individuals will participate in crowdlending despite obstacles and costs because the individuals can see bigger purposes based on their logical calculations, to help pioneering the birth of a new business that will provide job opportunities for other individuals' well-being (e.g. "I am willing to lend my money for crowdlending project because I think my assistance will bring welfare for others"). Johansson-Stenman (2012) found out that young individuals with university degrees and high incomes tend to embrace consequentialist moral judgment more than individuals from different groups. Therefore, the first hypothesis (H1) of this present study was "The higher the consequentialism moral judgment, the higher the prosocial value endorsing crowdlending behavior."

Individuals with deontological perspective believe that human beings, in fact, have moral responsibilities to fulfill (Tanner, Medin and Iliev, 2007; Robinson, 2012). Individuals who embrace deontology will participate in crowdlending because it could accomplish a religious mission, as a pivotal source of moral obligations, that requires the believers to give, or satisfy social norms suggesting people to help others (e.g.: "I am willing to lend my money for crowdlending project because it is my responsibility to help others"). Compared to those with consequentialism, individuals hold deontology perspective are perceived to be more prosocial, put less priority over their self-interest, as well as more reliable, closer to intuitive and emotional aspects, have more correlation with harm aversion, and have negative correlation with anti-social personality (Bartels and Pizarro, 2011; Everett, Pizarro and Crockett, 2016; Koenigs, Kruepke, Zeier and Newman, 2012; Kreps and Monin, 2014). Therefore, the second hypothesis $(\mathrm{H} 2)$ of this present study was "The higher the deontology moral judgment, the higher the prosocial value endorsing crowdlending behavior."

However, the Capraro et al (2017)'s study found out that both perspectives, consequentialism and deontology, have equal prosocial aspects; none is less than the other. Both perspectives can equally explain how individuals make a judgment about good and bad behavior (Uhlmann, Pizarro and Diermeier, 2015), and, as the implication, how individuals decide to participate in a prosocial behavior as fund lenders in crowdlending sites, with a totally different background of moral perspective and thinking process. This assumption is supported by the explanation of dual-process theory in which the two factors (both consequentialism and deontology) contribute in moral judgment formation and decision making (Greene, 2008). Therefore, the third hypothesis (H3) of this present study was "Both consequentialism and deontology moral judgment can predict the prosocial value endorsing crowdlending behavior in positive directions." 
This study will provide a scientific base to encourage Indonesians' participation in crowdlending that can be used by social entrepreneurs involved in crowdlending to promote relevant ethical role models and realize better social movements.

This study aimed at answering "Can consequentialism and/or deontology predict online prosocial value endorsing crowdlending behavior?" If yes, "Which one is stronger in predicting the value?"

\section{Methods}

\subsection{Participants and Design}

One hundred and ninety-eight individuals participated in this quantitative research (94 males, 105 females; mean of age $=30.56$ years, standard deviation of age $=6.06$ years). Fifty-seven participants resided in Jakarta (the capital of Indonesia), 62 in Tangerang, 16 in Bogor, 10 in Depok, 4 in Bekasi, and 49 outside Greater Jakarta. Most participants (63) are Javanese, 25 are Sundanese, 10 Minangkabaunese, 4 Bataknese, 8 Bantenese, 5 Betawinese, 5 Balinese, 1 Acehnese, 2 Kalimantanese. As much as 61 participants stated that they are of mixed ethnic groups (more than two ethnic groups), 10 identified themselves as from "other ethnic groups", and 4 did not answer the question.

The latest educational backgrounds of the participants were Bachelor (142), Master or Doctor (27), Diploma III (25), and Senior High School (4). As much as 129 participants were private sector employees, 27 civil servants, 18 entrepreneurs, 13 professionals, 5 freelancers, 4 housewives, and 2 others stated "others". As much as 8 participants stated that their monthly income was around 500,000-1,500,000 IDR, 24 stated 1,500,000-3,000,000 IDR, 58 stated 3,000,000-5,000,000 IDR, 56 stated 5,000,000-7,000,000 IDR, 36 stated 7,000,00010,000,000 IDR, 15 stated 10,000,000-15,000,000 IDR, and 1 stated above 15,000,000 IDR.

The design of this study is quantitative, predictive correlational. Multiple linear regression was used to know the predictive relationship between 2 independent variables (consequentialism, deontology) and a dependent variable (prosocial value endorsing online crowdlending behavior).

\subsection{Measurement}

To measure prosocial value in the context of online crowdlending, Prosocial Value scale constructed by Ladebo (2004) was adapted, referred by Wang and Wang (2008). This value is assumed to be internalized and becomes behavior guideline (Eyal et al, 2009). Participants were asked to state their agreement with each statement in 5-point Likert scale ( 1 = "Strongly Disagree", 5 = "Strongly Agree"). The items are "I will think of the feelings of the CL initiators", "I think helping CL initiators will be important", "I will help the CL initiators as much as possible", "I would be glad to be able to interact with CL initiators", and "It would be easy for me to act on the CL website as a lender of funds" ( 5 items, Cronbach's $\alpha=0.619$; Corrected item-total correlations $=0.403-0.641$ )

To measure to what extent the tendency of individuals to agree, embrace, and implement consequentialism or deontology, the Consequentialist Scale constructed by Robinson (2012) was used. Participants indicated to what extent they agree with the following statements in 5- 
point Likert scale ( 1 = "Strongly Disagree", $5=$ "Strongly Agree"). The items in the Consequentialist Scale were adapted to the crowdlending context in Indonesian.

The examples of items of Consequentialism scale ( 6 items, Cronbach's $\alpha=0.692$; Corrected item-total correlations $=0.269-0.587$ ) are as follow: "When I lend money in CL site, there is happiness/benefit for many people", "Help CL initiator can be morally justified because it brings many benefits".

The examples of items of Deontology scale (5 items, Cronbach's $\alpha=0.684$; Corrected item-total correlations $=0.301-0.503$ ) are as follow: "By helping CL initiator, I have fulfilled my responsibility to always do good deeds", "My life rule/principle requires me to help others, one of the way is through CL activity".

This study also added some questions at the end of the questionnaire to enrich the answers. Participants were instructed to imagine that they had enough abilities and resources to participate in crowdlending sites as fund lenders. They were asked about their interest in lending fund in crowdlending sites and the reasons.

\section{Results}

Multiple linear regression showed $F(2,197)=39.628, p=0.000, R^{2}$ (Effect size) $=$ $28.9 \%$. The higher the consequentialism ( $B=0.506, S E B=0.075, \beta=0.456, t=6.789, p<$ $0.01)$ the higher the prosocial value endorsing online crowdlending behavior. The higher the deontology $(B=0.378, S E B=0.171, \beta=0.149, t=2.213, p<0.01)$ the higher the prosocial value endorsing online crowdlending behavior (Table 1). Therefore, H1, H2, and $\mathrm{H} 3$ were supported by empirical data.

Table 1: Multiple linear regression predicting prosocial value endorsing online crowdlending behavior $(n=198)$.

\begin{tabular}{lccc}
\hline Predictor & $\beta$ & $t$ & $p$ \\
\hline Consequentialism & 0.456 & 6.789 & 0.000 \\
Deontology & 0.149 & 2.213 & 0.000 \\
\hline
\end{tabular}

\section{Discussions}

The significance of consequentialism moral judgment in predicting prosocial behavior can be explained by discussing one of the cultural values in Indonesia, collectivism. Hofstede (2011) defined collectivism as a state of mind that all in-groups values and goals are the main points, to what extent individuals integrate themselves into their closest group. Hofstede's (Hofstede, Hofstede and Minkov, 2010; Hofstede, 2011) study still holds the conclusion that collectivism in Indonesia is very high. Individuals living in a country with a strong collectivist culture are proven to have higher empathy and prosocial behavior because there is a stronger will to satisfy communal goals than personal goals (Chopik, O'Brien and Konrath, 2016; Irwin, 2009). Consequentialism moral judgment focusing on "the greatest happiness of the greatest number" motto (Bertens, 1997; Brink, 2006) is in line with collectivist values that highly appreciate a collaborative harmonious life (Rinuastuti et al, 2014; Luria, Cnaan and Boehm, 2014). In Indonesia, that is proven by "gotong royong" concept, i.e. working together, helping each other (KBBI Daring, 2016), the deepest core of Pancasila (Five Principles)-the 
Indonesian state ideology (Dewantara, 2016). Fundraising activities on the internet for a particular issue are the manifestation of the strongly rooted gotong royong spirit of Indonesians via a more modern media, catching up with technology development (Gea, 2016). In crowdlending concept, "digital gotong royong" concept clearly serves as the basic function and method of the crowdlending activities.

In moral theory, consequentialist paradigm believes that every behavior with positive impacts (happiness, satisfaction, and welfare) for as many people as possible is morally justified (Rosenberg, 2008; Spielthenner, 2005; Tiberius and Plakias, 2010). Crowdlending (CL) initiator tries to promote his/her business activities to gain financial aid by stressing more on the positive impacts for many people. The wider the potential positive influences of a small enterprise could be, the bigger the intention of individuals to contribute. The statement is strengthened by the result of the analysis of additional descriptive-qualitative data obtained by the researcher. Of 113 participants saying that they had interest to contribute as fund lenders in crowdlending sites, most of them emphasized the willingness to help many people in general (e.g. "I want to help many people", "I want to be the agent of social changes", and "I want to contribute to nation and country's development").

As the practical implication, it would be better if in explaining the significance of his/her business activities, CL initiator explains the social benefit and who can feel the impacts of these business activities supported with facts and data. The example is one of the small enterprises in GandengTangan (https://gandengtangan.org/) site-"HoldHands" in English-that proposes support for capital to facilitate women farmers in Southeast Sulawesi (https://gandengtangan.org/pemberdayaan-kelompok-wanita-tani-dan-kegiatan-home-

industri). The business proposal achieves the funding targets proposed owing to the detailed explanation of the benefits in its business description. Initiator emphasizes how the business can help more than 50 households around the small business who are of the low economic background by empowering women and housewives who stay at home and cultivating unused lands. Besides that, we can see an example of Komodo Water small enterprise promising the availability of clean drinking water for people in Komodo Islands that used to be very limited (https://gandengtangan.org/komodo-water). The initiator effectively includes five reasons of why the need of clean water for people in Komodo Islands is very urgent. The initiator also explains that Komodo Water business will provide clean water daily for at least 2,000 households in Komodo Island. There is also Du'Anyam enterprise that provides job opportunities for pregnant and breast-feeding women in Flores, East Nusa Tenggara (https://gandengtangan.org/duanyam). The purpose is noble, to give additional income for pregnant and breastfeeding women in the area that they can access health, nutrition, and healthy lifestyle facilities.

The essence of deontology is that good or bad a behavior is judged from its obligation regardless the consequences it brings. In crowdlending, obligation fulfillment is an inseparable element. It can be seen from the answer of additional questions gathered by the authors. Most of the participants who were willing to help stated that by participating in crowdlending, they have accomplished the obligation to help others, to do good deeds, to worship God, and to give. It seems that there are some unwritten communal norms that every member of the society has as his/her own everyday life responsibility, such as help others in need, especially if he/she can do that (Batson and Powell, 2003; Bénabou and Tirole, 2010; Al Khoury et al, 2013). The rules we are exposed to can be learned and internalized in such a way that it becomes a personal standard or norm that we apply to ourselves (Batson and Powell, 2003). In the context of prosocial behavior, individuals with personal norms will feel the sense of obligation to exhibit it. 
One of the rules strongly held by most of Indonesians is the religious rule. It cannot be denied that religion has a big role in many life domains in Indonesia (Bagir, 2015; Hosen, 2005). Religious education is instilled since an early age and is continued in any level of education, in pesantren (Islam boarding school) or seminary, or in general education (Susanto, 2009). The constant and persistent teachings of religion delivered to most Indonesians since early age make Indonesians familiar with religious rules, and then make them as life guidelines. In this way, the obligation to help others taught by every religion becomes the gold standard of good or bad of a behavior. An example of financial aid proposal that emphasizes on the moral rules is the proposal to build a pesantren promoted via KitaBisa-"WeCan" in English (Kurniadi et al, 2014)-site (https://kitabisa.com/buatpesantrentahfidz). Its description states that the initiator provides a chance to endow and the "reward" will be given to the contributor for the rest of his/her life even eternally, touching the emotional side of the contributor candidates. It is legitimate for an initiator in crowdlending sites to include emotional aspects and target the contributor's obligation or responsibility in the pitching materials or description during the fundraising in crowdlending sites. However, as consequentialism has its unique predictive role, too, it will be better if the initiator put also data, urgency, and the fact that the small enterprise will be beneficial for many people.

Why is consequentialism stronger than deontology in predicting the prosocial value endorsing crowdlending behavior? Prioritizing consequentialism above deontology in Indonesian people has been indicated previously by Tjandra, Ensor and Thomson (2014). In the context of tobacco marketing in Indonesia, they found that practices in Indonesia are intensely opposed to deontology principles. Authorities and policymakers have stressed the economic benefits of the tobacco industry. The Indonesian population is assumed to have relied on the tobacco industry. Disease and death from cigarettes are not denied but is considered a "minor" amount, so the Indonesian regulation has minimal restriction on cigarettes (Tjandra, Ensor and Thomson, 2014). This is one example of how the social structure of Indonesian society endorse consequentialism. Cigarette advertisements are made in such a way that always awake innovativeness and creativity. This is very contrary to deontology which has the principle that "to use clearly effective communications to sell a deadly product is unethical" (Tjandra, Ensor and Thomson, 2014, p6).

In addition, stronger consequentialism or utilitarianism ethical judgment in predicting prosocial value endorsing crowdlending behavior can not be separated from the Indonesian view of life, namely Pancasila (Five Principles), as stated above. However, Darmaputera (1988, p219-220) expressed a critical evaluation of the inclusiveness of Pancasila,

"the limitation of Pancasila is not because it is inclusive, but because it is not inclusive enough .... It is clear that the limitations of Pancasila are rooted in the weaknesses and the insufficiencies of the traditional value conception. The biggest problem of Indonesia is, thus, not how to defend or to change Pancasila, but how to overcome these cultural problems. What it needs is cultural and value transformation."

The disadvantage of the inclusive ethical approach is to exaggerate the complexity of reality, making the negation of the "either-or" (exclusive) approach (which is endorsed by deontology) (Darmaputera, 1988). But because of that, (1) the "limited inclusiveness" creates its "own exclusiveness", because (2) generally one still has to choose between "white" and "black", to be "inside" or "outside" of inclusiveness (and can not avoid the decisional situation), meanwhile (3) to be "outside of inclusiveness" is considered a badness that must be resisted; however, to understand the good we also need to understand the evil. The challenge for inclusiveness in Indonesia is that: 
"the traditional Indonesian world-view is not a fertile soil for the idea of the basic human rights to grow .... It stems from the understanding of the ultimate reality as transcendent of any finite categorization, hence it is unknowable, indescribable, ineffable .... Koentjaraningrat has shown that the traditional values are able to work in small scale societies with a strong agricultural background, namely in the 'desa' (rural) type of society. It is here that values such as gotong royong (mutual help) and musyawarah untuk mufakat (deliberation for unanimous consensus) can sustain the solidarity structure. But with urbanization, industrialization, and social development, it has to be consciously restructured." (Darmaputera, 1988, p217).

Ethical discourses from Darmaputera (1988) are able to explain the findings of this present study. Consequentialism has more predictive strength because traditional values prevailing in Indonesian society are generally less enthusiastic in facilitating an ethical approach of deontology that makes categorization or separation between "right and wrong", "good and bad" firmly. However, consequentialism faces challenges from within and from outside. Challenges from within, philosophically, consequentialism rest on "bounded solidarity", solidarity based on population coverage and limited values as well. If the definition of the "greatest number" of consequentialism does not undergo continuous redefinition, consequentialism is very vulnerable to "fall" in prosocial behavior (e.g. crowdlending) benefitting only certain groups referred to and defined by those in high social hierarchies. In addition, consequentialism without deontology would tend to ignore individual's human rights and less consider the individual weight of each social problem requiring social coordination such as crowdlending behavior.

Nevertheless, the combination of consequentialism and deontology also contains a complicated problem. For example, in Indonesia, Nusron Wahid's expression that "Above the religious and customary law is the Republic constitution" reaps unnecessary controversy because it stimulates a misunderstanding (Riady, 2015). Religious-based deontology seems to clash with public ethics. Riady argued that the solution to the illusory debate is an accurate understanding of the level of unit analysis of Wahid's talks that: "He (Wahid) does not place the constitution as the ultimate guidance of the individual, but the ultimate guideline in a coexistent life in a Republic, a kind of common denominator not to clash with individual claims of truth. Like red-light at the road intersection; Muslims, Hindus, and Atheists alike, must stop. They each should not feel more powerful and immune from the red-light signal." Thus, the consequentialism knit with deontology needs to be designed carefully in order to produce the most effective and just resultant. In common life, public benefit needs to be put forward without recklessly sacrificing the values of existing rules.

\section{Conclusion}

This study concludes that consequentialism and deontology moral judgment are able to predict the prosocial value endorsing crowdlending behavior in positive directions. This present study deliberately discusses its results by describing the life philosophies and discourses that take place in Indonesia because the authors believe that the engagement of crowdlending behavior in Indonesia needs to seriously consider social psychological reality of Indonesians. The limitation of the study is that the most participants were from towns or regions in Java such as Cirebon, Bandung, Surabaya, and one dominating region, the Greater Jakarta (Jakarta, Bogor, Depok, Tangerang, and Bekasi). Subsequent research is expected to recruit participants from outside Java to expand the scope of generalization of this study. 


\section{References}

[1] Al Khoury, P., Al Kotob, M., Temraz, L. and Kamar, M. (2013) 'The motive for individual social responsibility and its possible impacts: The case of Lebanon', American Academic \& Scholarly Research Journal, 5(6), p1-23.

[2] Aronson, E., Wilson, T.D. Akert, R.M. and Sommers, S.R. (2016) Social psychology. 9th ed. Upper Saddle River, NJ: Pearson Prentice Hall.

[3] Bagir, Z.A. (2015) 'The importance of religion and ecology in Indonesia', Worldviews: Global Religions, Culture, and Ecology, 19(2), p99-102. Available at: https://doi.org/10.1163/1568535701902002.

[4] Bank Indonesia. (2015) Profil bisnis usaha mikro, kecil, dan menengah (UMKM). Jakarta, Indonesia: LPPI \& Bank Indonesia [Online]. Available at: http://www.bi.go.id/id/umkm/penelitian/nasional/kajian/Documents/Profil\%20Bisnis\%20UMK M.pdf (Accessed: 3 February 2018).

[5] Bartels, D.M. and Pizarro, D.A. (2011) 'The mismeasure of morals: Antisocial personality traits predict utilitarian responses to moral dilemmas', Cognition, 121(1), p154-161. Available at: https://doi.org/10.1016/j.cognition.2011.05.010.

[6] Batson, C.D. and Powell, A.A. (2003) 'Altruism and prosocial behavior' in Millon, T., Lerner, M.J. and Weiner, I.B. (eds.) Handbook of psychology: Personality and social psychology. Hoboken, NJ: John Wiley \& Sons, Inc., vol. 5, pp. 463-484.

[7] Bénabou, R. and Tirole, J. (2010) 'Individual and corporate social responsibility', Economica, 77(305), p1-19. Available at: https://doi.org/10.1111/j.1468-0335.2009.00843.x.

[8] Bertens, K. (1997) Etika. Jakarta, Indonesia: PT Gramedia Pustaka Utama.

[9] Brink, D.O. (2006) 'Some forms and limits of consequentialism' in Copp, D. (ed.) The Oxford handbook of ethical theory. New York: Oxford University Press, Inc., pp. 380-423.

[10] Capraro, V., Sippel, J., Zhao, B., Hornischer, L., Savary, M., Terzopoulou, Z., Faucher, P. and Griffioen, S.F. (2017) Are Kantians better social partners? People making deontological judgments are perceived to be more prosocial than they actually are [Online]. Available at: https://ssrn.com/abstract=2905673 (Accessed: 3 February 2018).

[11] Chopik, W.J., O'Brien, E. and Konrath, S.H. (2016) 'Differences in empathic concern and perspective taking across 63 countries', Journal of Cross-Cultural Psychology, 48(1), p1-16. Available at: https://doi.org/10.1177/0022022116673910.

[12] Darmaputera, E. (1988) Pancasila and the search for identity and modernity in Indonesian society: A cultural and ethical analysis. Leiden, Netherlands: Brill.

[13] Dewantara, A.W. (2016) 'Gotong-royong menurut Soekarno dalam perspektif aksiologi Max Scheler, dan sumbangannya bagi nasionalisme Indonesia' Doctoral dissertation. Universitas Gadjah Mada, Yogyakarta, Indonesia [Online]. Available at: http://etd.repository.ugm.ac.id/downloadfile/97623/potongan/S3-2016-355105-Abstract.pdf (Accessed: 7 February 2018).

[14] Eisenberg, N. (1982) The development of prosocial behavior. New York, NY: Academic Press.

[15] Everett, J.A., Pizarro, D.A. and Crockett, M.J. (2016) 'Inference of trustworthiness from intuitive moral judgments', Journal of Experimental Psychology: General, 145(6), p772-787.

[16] Eyal, T., Sagristano, M.D., Trope, Y., Liberman, N. and Chaiken, S. (2009) 'When values matter: Expressing values in behavioral intentions for the near vs. distant future', Journal of Experimental Social Psychology, 45(1), p35-43. Available at: https://doi.org/10.1016/j.jesp.2008.07.023.

[17] Galak, J., Small, D. and Stephen, A.T. (2011) 'Microfinance decision making: A field study of prosocial lending', Journal of Marketing Research, 48(SPL), pS130-S137. Available at: https://doi.org/10.1509/jmkr.48.SPL.S130.

[18] Gea, F.D.S. (2016) 'Crowdfunding: Gerakan baru kegotongroyongan di Indonesia (Tinjauan evolusi gerakan aksi kolektif dalam media baru)' in Proceeding of Konferensi Nasional Sosiologi $V$ Asosiasi Program Studi Sosiologi Indonesia: Gerakan Sosial dan Kebangkitan Bangsa, Padang, Indonesia, pp. 1-23. Available at: http://www.academia.edu/27878870/CROWDFUNDING_GERAKAN_BARU_KEGOTONGR 
OYONGAN_DI_INDONESIA_TINJAUAN_EVOLUSI_GERAKAN_AKSI_KOLEKTIF_DAL AM_MEDIA_BARU_(Accessed: 7 February 2018).

[19] Gerber, E.M., Hui, J.S. and Kuo, P.Y. (2012) 'Crowdfunding: Why people motivated to post and fund projects on crowdfunding platforms', in Proceedings of the International Workshop on Design, Influence, and Social Technologies: Techniques, Impacts and Ethics, 2 [Online]. Available

https://www.researchgate.net/publication/261359489_Crowdfunding_Why_People_are_Motivate

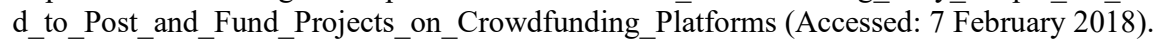

[20] Gerber, E.M., Muller, M., Wash, R., Irani, L.C., Williams, A. and Churchill, E.F. (2014) 'Crowdfunding: An emerging field of research' in CHI'14 Extended Abstracts on Human Factors in Computing Systems, New York, NY: ACM, pp. 1093-1098.

[21] Ghanimeh, G. (2015) Social entrepreneurs don't have it easy raising capital [Online]. Available at: https://www.entrepreneur.com/article/242206 (Accessed: 3 February 2018).

[22] Greene, J.D. (2008) 'The secret joke of Kant's soul' in Sinnott-Armstrong, W. (ed.) The neuroscience of morality: Emotion, brain disorders, and development. Cambridge: The MIT Press, vol. 3, pp. 35-79.

[23] Hemer, J. (2011) 'A snapshot on crowdfunding', Working Papers Firms and Region, No. R2/2011. Karlsruhe, Germany: Fraunhofer Institute for Systems and Innovation Research (ISI). Available at: http://www.legalefiscale.it/wp-content/uploads/2016/09/StudioCrowdfundig.pdf (Accessed: 3 February 2018).

[24] Hofstede, G. (2011) 'Dimensionalizing cultures: The Hofstede Model in context', Online Readings in Psychology and Culture, 2(1), p1-26. https://doi.org/10.9707/2307-0919.1014.

[25] Hofstede, G., Hofstede, G.J. and Minkov M. (2010) Cultures and organizations: Software of the mind. 3rd ed. New York, NY: McGraw-Hill Education.

[26] Hosen, N. (2005) 'Religion and the Indonesian constitution: A recent debate', Journal of Southeast Asian Studies, 36(3), p419-440.

[27] Irwin, K. (2009) 'Prosocial behavior across cultures: The effects of institutional versus generalized trust' in Thye, S.R. and Lawler, E.J. (eds.) Altruism and prosocial behavior in groups (Advances in group processes, vol. 26). Bingley, UK: Emerald Group Publishing Limited, pp. 165-198.

[28] Johansson-Stenman, O. (2012) 'Are most people consequentialists?', Economics Letters, 115(2), p225-228.

[29] KBBI Daring. (2016) Gotong royong [Online]. Available at: https://kbbi.kemdikbud.go.id/entri/Gotong\%20royong (Accessed: 3 February 2018).

[30] Kementerian Koperasi dan Usaha Kecil dan Menengah. (2017) Ratio wirausaha Indonesia naik jadi 3,1 persen [Online]. Available at: http://www.depkop.go.id/content/read/ratio-wirausahaindonesia-naik-jadi-31-persen/ (Accessed: 7 February 2018).

[31] Koenigs, M., Kruepke, M., Zeier, J. and Newman, J.P. (2012) 'Utilitarian moral judgement in psychopathy', Social Cognitive and Affective Neuroscience, 7(6), p708-714. Available at: https://doi.org/10.1093/scan/nsr048.

[32] Kreps, T.A. and Monin, B. (2014), 'Core values versus common sense: Consequentialist views appear less rooted in morality', Personality and Social Psychology Bulletin, 40(11), p1529-1542. Available at: https://doi.org/10.1177/0146167214551154.

[33] Kurniadi, M., Fresty, F., Kwan, K., Sharron, S. and Abraham, J. (2014), 'Are we still giving our money to beggars? Prosocial intention in between of religion, emotion, corruption, and government policy advocacy', Mediterranean Journal of Social Sciences, 5(23), p1817-1826.

[34] Ladebo, O. (2004) 'Employees' personal motives for engaging in citizenship behavior: The case of workers in Nigeria's agriculture industry', Current Research in Social Psychology, 9(16), 220 234.

[35] Lampridis, E. and Papastylianou, D. (2014) 'Prosocial behavioural tendencies and orientation towards individualism-collectivism of Greek young adults', International Journal of Adolescence and Youth, 22(3), p268-282. Available at: https://doi.org/10.1080/02673843.2014.890114. 
[36] Larry, A. and Moore, M. (2016) 'Deontological ethics' in Zalta, E.N. (ed.) Stanford Encyclopedia of Philosophy. Winter 2016 ed. [Online]. Available at: https://plato.stanford.edu/entries/ethics-deontological/ (Accessed: 3 February 2018).

[37] Luria, G., Cnaan, R.A. and Boehm, A. (2014) 'National culture and prosocial behaviors: Results from 66 countries', Nonprofit and Voluntary Sector Quarterly, 44(5), 1041-1065. Available at: https://doi.org/10.1177/0899764014554456.

[38] Penner, L.A., Dovidio, J.F., Piliavin, J.A. and Schroeder, D.A. (2005) 'Prosocial behavior: Multilevel perspectives', Annual Reviews of Psychology, 56, p365-392.

[39] Riadi, F. (2015) Di atas hukum agama dan adat ada konstitusi negara [Online]. Available at: https://www.kompasiana.com/himung/di-atas-hukum-agama-dan-adat-ada-konstitusinegara_54f4169a7455137d2b6c8642 (Accessed: 3 February 2018).

[40] Rinuasturi, H., Hadiwidjojo, D., Rohman, F. and Khusniyah, N. (2014) 'Measuring Hofstede's five cultural dimensions at individual levels and its application to researchers in tourists' behaviors', International Business Research, 7(12), p143-153. Available at: https://doi.org/10.5539/ibr.v7n12p143.

[41] Robinson, J.S. (2012) 'The Consequentialist Scale: Elucidating the role of deontological and utilitarian beliefs in moral judgments' Master's thesis, University of Toronto, Canada [Online]. Available at: https://tspace.library.utoronto.ca/bitstream/1807/33868/3/Robinson_Jeffrey_S_201211_MA_thes is.pdf.

[42] Rosenberg, A. (2008) Philosophy of social science. 3rd ed. Boulder, CO: Westview Press.

[43] Spielthenner, G. (2005) 'Consequentialism or deontology?', Philosophia, 33(1-4), p217-235. Available at: https://doi.org/10.1007/BF02652653.

[44] Sulaiman, S.R. (2015) "Social entrepreneurship", perpaduan bisnis dan sosial ala IDEAFEST 2015. [Online]. Available http://bisniskeuangan.kompas.com/read/2015/04/01/184848226/.Social.Entrepreneurship.Perpad uan.Bisnis.dan.Sosial.ala.IDEAFEST.2015 (Accessed: 3 February 2018).

[45] Susanto, E. (2009) 'Pendidikan agama dalam sistem pendidikan di Indonesia (Survey Historis Era Pemerintahan Soekarno)', Tadris, 4(1), 35-54.

[46] Tanner, C., Medin, D.L. and Iliev, R. (2007) 'Influence of deontological versus consequentialist orientations on act choices and framing effects: When principles are more important than consequences', European Journal of Social Psychology, 38(5), p1-13.

[47] Tiberius, V. and Plakias, A. (2010) 'Well-being' in Doris, M.J., Harman, G., Nichols, S., Prinz, J., Sinnott-Armstrong, W. and Stich, S. (eds.) The moral psychology handbook. New York, NY: Oxford University Press, pp. 402-432.

[48] Tjandra, N.C., Ensor, J. and Thomson, E. (2014) 'Tobacco children: An ethical evaluation of tobacco marketing in Indonesia', in Proceedings of International Marketing Trends Conference, Venice, 24-25 January 2014, pp. 1-11. Available at: http://www.marketing-trendscongress.com/archives/2014/pages/PDF/327.pdf (Accessed: 7 February 2018).

[49] Uddin, M.A. (2014) 'Problems faced by micro, small, and medium enterprises in raising debt capital' in Bin Basri, M., Salleh, M.S.M., Arshad, S.R. and Ahmad, C.W.S.B. (eds.) Proceeding of the Social Sciences Research (ICSSR 2014), Selangor, Malaysia: Kolej Universiti Islam Antarabangsa Selangor (KUIS), pp. 176-186.

[50] Uhlmann, E.L., Pizarro, D.A. and Diermeier, D. (2015) 'A person-centered approach to moral judgement', Perspectives on Psychological Science, 10(1), p72-81. Available at: https://doi.org/10.1177/1745691614556679.

[51] Underwood, B. and Moore, B.S. (1982) 'The generality of altruism in children' in Eisenberg, N. (ed.) The development of prosocial behavior. New York, NY: Academic Press, pp. 25-49.

[52] Wang, C.C. and Wang, C.H. (2008) 'Helping others in online games: Prosocial behavior in cyberspace', CyberPsychology \& Behavior, 11(3), 344-346. Available at: https://doi.org/10.1089/cpb.2007.0045. 